\title{
Erythrina Sub Umbrans as Hot and Cold Compression Therapy for Engorgement and Pain Intensity in Breast during Post Natal Bleeding
}

\author{
Sri Rahayu', Ida Ariyanti ${ }^{2}$ \\ ${ }^{1,2}$ Midwifery Department, Politeknik Kesehatan Kemenkes, Semarang, Indonesia
}

*Corresponding Author: Sri Rahayu, Midwifery Department, Politeknik Kesehatan Kemenkes, Semarang, Indonesia.Email: yayoekSR_74@yahoo.com

\begin{abstract}
Background: Breastfeeding problems that often occur in the early postpartum period are clogged breast milk ducts and swollen breasts which are commonly treated with compression therapy.

The Objective: This study aims to determine the healing effectiveness between the use of Erythrina Sub Umbrans leaves-locally known as"daun dadap serep" compared with conventional cold-hot compression.

Method: this research applied non-equivalent control group design with pretest and post test with 81 respondents divided proportionally into 2 (groups); those who treated with Erythrina Sub Umbrans leaves and those with cold-hot compression. Wilcoxon and Mann Whitney test were used to confirm the different of healing effectiveness between the two groups.
\end{abstract}

Result: Both dadap serep leaves and hot-cold compression can reduce pain and swelling breast. The Mann Whitney test in both groups showed no difference between the leaf and hot-cold compresses in reducing postpartum breast pain and swelling.

Conclusion: Socialization is needed to the community, especially the postpartum women in the utilization of the leaf as an alternative compression therapy in reducing swelling and pain in the breast.

Keywords: Compression, Erythrina Sub Umbrans, Breast Swollen.

\section{INTRODUCTION}

Breastfeeding is a significant activity for mother and baby because during the breastfeeding process there will be a close relationship between mother and child. Several breastfeeding problems often occur in the early postpartum such as droplets or flat nipples, nipple blisters, clogged breast milk ducts, swollen breasts, and eventually mastitis to the abscess (Leveno, 2009).

Around the third or fourth day after the mother gives birth, the breasts often feel fuller, tense, and painful. In this condition, the mother usually avoids breastfeeding for reasons of pain leading to prelacteal feeding in infants (Prawirohardjo, 2009). Pain in the breast can be overcome by frequent on-demand as often as possible, hot compresses, cold breast compress before being pierced, breast massage, cold breast compresses between breastfeeding (Saifuddin, 2009).
Besides, traditional medicinal plants such as leaves dadap serep (Erythrina Sub umbrans) can be used as an analgesic and antipyretic drugs (Rukachaisirikul et. al, 2007). Some studies also mention the leaves of dadap serep is useful as an antioxidant, muscle relaxation and anti-bacterial (Kumar.A, 2010). The purpose of this research is to know the effect of the average difference between the leaf and hotcold compress in reducing breast engorgement and intensity of pain in a group of the puerperal mother.

\section{MATERIALS AND METHODS}

The research design is nonequivalent control group design with pretest and post test. The population of this research is puerperal mothers in 4 (four) Healthcare Community Centers Semarang Regency. The number of groups I samples was leaf dadap serep compression of 40 and group II hot-cold compression of 41 
Erythrina Sub Umbrans as Hot and Cold Compression Therapy for Engorgement and Pain Intensity in Breast during Post Natal Bleeding

taken consecutively. Data were analyzed with Wilcoxon and Mann Whitney test while confounding variables were analyzed with MANCOVA.

\section{RESULT AND DISCUSSION}

Characteristics of respondents in two groups are presented in Table 1.

Table1. Characteristics of respondents

\begin{tabular}{|c|c|c|c|}
\hline \multirow[t]{2}{*}{ Variables } & \multicolumn{2}{|c|}{ Groups } & \multirow[t]{2}{*}{$\mathbf{P}^{*}$} \\
\hline & $\begin{array}{c}\text { The leaf } \\
\text { compression } \\
\text { Median (min- } \\
\max ) \\
\mathrm{n}(\%)\end{array}$ & $\begin{array}{c}\text { Hot-cold } \\
\text { compression } \\
\text { Median (min- } \\
\max ) \\
\mathrm{n}(\%)\end{array}$ & \\
\hline Ages & $28(18-39)$ & $29(16-43)$ & 0.469 \\
\hline Parity & $2(1-4)$ & $2(1-5)$ & 0.316 \\
\hline $\begin{array}{l}\text { EDUCATION } \\
\text { Elementary } \\
\text { Secondary } \\
\text { Higher }\end{array}$ & $\begin{array}{cc}17 & (42.5 \%) \\
21 & (52.5 \%) \\
2 & (2.5 \%) \\
\end{array}$ & $\begin{array}{c}9(22 \%) \\
25(61 \%) \\
7(17.1 \%) \\
\end{array}$ & 0.171 \\
\hline $\begin{array}{l}\text { MOTIVATION } \\
\text { Good } \\
\text { Less }\end{array}$ & $\begin{array}{l}27(67.5 \%) \\
13(32.5 \%)\end{array}$ & $\begin{array}{l}23(56.1 \%) \\
18(43.9 \%)\end{array}$ & 0.079 \\
\hline
\end{tabular}

*Uji Mann Whitney test

Respondents were mostly still in the reproductive age and cooperative in responding to a problem of pain in the breast. The education level of the two groups was at secondary level, so it was relatively easy to absorb the information (Murniati, 2013). The motivation of mothers in breastfeeding in both groups was mostly good. This condition would encourage parents to remain eager in breastfeeding their babies despite the problems of engorgement and pain in both breasts. Motivation can be interpreted as a person's strength or energy that can lead to the level of persistence and enthusiasm in carrying out an activity, either from within the individual itself or from outside the individual (Akhmad S, 2008). The puerperal mothers who still have less motivation need support from the surrounding environment both family and health workers. This finding supported the previous research that there was a very significant positive relationship between social support (husband) with motivation to give exclusive breastfeeding to mothers (Sopiyani, 2014).

Descriptive analysis of pain and engorgement rates on respondents is shown in Table 2.
Table2. Description of pain and engorgement rates before treatment

\begin{tabular}{|l|l|l|l|}
\hline Variables & \multicolumn{2}{|c|}{ Groups } & \multirow{2}{*}{ p } \\
\hline & $\begin{array}{c}\text { The leaf } \\
\text { compression } \\
\text { Median } \\
(\text { minmax }) \\
\mathrm{n}(\%)\end{array}$ & $\begin{array}{c}\text { Hot-cold } \\
\text { compression } \\
\text { Median } \\
(\text { min-max }) \\
\mathrm{n}(\%)\end{array}$ & \\
\hline Pain rate & $5.2 \pm 1.68$ & $6.05 \pm 1.32$ & $0.394^{*}$ \\
\hline $\begin{array}{l}\text { Engorgement } \\
\text { rate }\end{array}$ & $3.73 \pm 0.78$ & $4.78 \pm 0.419$ & $0.89^{*}$ \\
\hline
\end{tabular}

\section{"Lavene Test}

The mean score of respondent pain in both groups before treatment was 5.2 and 6.02, meaning that it was in moderate pain level. The pain experienced by the postpartum mother during the first weeks of breastfeeding is a physiological state, but if left alone it will reduce milk production and inhibit success in breastfeeding (Lim Arora, 2008). Pain in the breast pain will cause a mother's reluctance in breastfeeding her baby, so that will cause other problems in the breast, for example, mastitis.

Differences in pain levels and engorgement before and after treatment in both groups are shown in Table 3.

Table3. Pain and engorgement rates before and after treatment

\begin{tabular}{|c|c|c|c|}
\hline \multirow[t]{2}{*}{ Variables } & \multicolumn{2}{|c|}{ Groups } & \multirow[t]{2}{*}{$p \infty$} \\
\hline & $\begin{array}{c}\text { The leaf } \\
\text { compression } \\
\text { Median } \\
\text { (min-max) } \\
\mathrm{n}(\%)\end{array}$ & $\begin{array}{c}\text { Hot-cold } \\
\text { compression } \\
\text { Median (min- } \\
\max ) \\
\mathrm{n}(\%)\end{array}$ & \\
\hline Pain & & & \\
\hline Before & $5.2 \pm 1.68$ & $6.05 \pm 1.32$ & 0.394 \\
\hline After & $2.78 \pm 1$ & $2.07 \pm 1.36$ & 0.866 \\
\hline$P^{*}$ & 0.0001 & 0.0001 & \\
\hline$\Delta$ & $2.43 \pm 1.10$ & $4.98 \pm 1.69$ & 0.0001 \\
\hline Engorgement & & & \\
\hline Before & $3.73 \pm 0.78$ & $4.78 \pm 0.419$ & 0.89 \\
\hline After & $2.20 \pm 0.687$ & $2.83 \pm 0.803$ & 0.278 \\
\hline$P^{*}$ & 0.0001 & 0.0001 & \\
\hline$\Delta$ & $1.53 \pm 0.599$ & $1.95 \pm 0.865$ & 0.010 \\
\hline
\end{tabular}

Table 3 shows both the leaf and hot -cold compresses indicates a significant difference in reducing breast pain and swelling $(\mathrm{p}$ - value $=$ 0.0001 in Wilcoxon test and $p$ - value $=0.01$ in Mann Whitney test). Compress of leaves dadap serep can be used as one alternative in reducing pain and swelling in the breast, in addition to cold- hot compress that has been long recommended as one way to reduce pain and 
swelling of the breast. This finding supported Khosravan (2015) that compresses can reduce pain in breast engorgement. Heat can relieve ischemic and blood vessels so that it relieves pain by reducing tension and improving feelings of well-being (Witt \& Bolman, 2015). Cold compresses can reduce static veins and pain. By doing hot and cold compress alternatively, can launch blood vessels in the breast. In line with previous research by Lim Arora (2008), that cold, hot compresses are more efficient at reducing swelling than compress leaves of cabbage. Similarly, according to Deswani, 2014, compress leaves of cabbage as a placebo can reduce breast engorgement.Hot or cold compresses can provide a sense of comfort. This effect causes the release of endorphins, thus blocking the transmission of painful stimuli. Local heat stimulation stimulates the receptors under the skin and activates the transmission of larger and faster beta sensory fibers (Guyton and Hill, 2007).

According to Nengah and Surianti (2013), hot compresses are considered useful to improve blood circulation, especially in postpartum breast engorgement. One of the pain reducers with non-pharmacological natural methods is hot and cold compresses. According to Genae D. Strong (2011), to reduce breast engorgement, babies need to drink more milk to help drain milk while breast swelling may subside with hot compresses and hot water showers in painful breast areas. Another study by A.-R., Song (2015), mentioned earlier breast care and treatment using cabbage leaves could be recommended to reduce pain and breast engorgement of the puerperium.

Leaf compresses are also effective in reducing pain and swelling of the breast, according to a previous study that with ethanol extract and leaf of dadap serep showed the presence of pressure acting on the central nervous, muscle relaxation sympatholytic and para sympathomimetic.

Dadap leaf plants are easy to get in the environment and easy to grow. How to do the compress with the leaf of dadap serep is very easy that is by using five strands of leaves, kneaded and twisted, then attached to both breasts swelling for 10-20 minutes and each time the leaves dry, they must be replaced with new leaves again.

The result of multivariate analysis with MANCOVA test showed that the variables of age, parity, education, and motivation of mother generated $p$-value $>0.05$, meaning there is no influence of age, parity, education, and parent motivation to decrease pain. This evidence means the four variables are not confounding variables. The occurrence of pain reduction is influenced by the leaf of dadap serep and hotcold compress which similarly also occurs on the decrease in engorgement. However, in the motivation variable, there is an effect on the drop of engorgement with the p- value of 0.03 meaning that motivation of mother to more frequent breastfeeding give the influence to decrease engorgement.

Parents who are motivated well will contribute to lowering engorgement. Motivation can be obtained from within and from outside himself. According to Mohrbacher \& Nancy, (2010), that breastfeeding is a natural process so that every mother should be able to do it. With a real motivation, it will support the success in reducing engorgement, so the sustainability in providing breast milk is possible.

\section{CONCLUSION}

- Leaves of dadap serep ( Erythrina Sub Umbrans) and hot-cold compression, both can reduce breast pain and swelling.

- There was a difference of decreasing pain and swelling in the leaf compress group and the hot-cold compress $(\mathrm{p}$-value $=0.01$ ). Hot-cold compresses are more efficient in reducing pain and swelling of the breast to dadap serep leaves.

- Age, parity, education do not affect in reducing pain and engorgement. There is no effect of motivation on the decrease of breast pain, but there is influence of motivation to reduce engorgement.

- It needs socialization to postpartum mother or health officer especially midwife in utilizing herbal plant the leaves of dadap serep as alternative in reducing engorgement besides with the conventional hot-cold compress.

\section{ACKNOWLEDGEMENT}

The researchers express gratitude to the Head of Health Office of Semarang Regency who has given the research permission and to the Director of Poltekkes Kemenkes Semarang for the support of health research fund in 2016. 


\section{REFERENCES}

[1] A.-R., Song, J.-A., Hur, M.-H., Lee, M.-K., \& Lee, M. S. (2015). Cabbage compression early breast care on breast engorgement in primiparous women after cesarean birth: a controlled clinical trial. International Journal of Clinical and Experimental Medicine, 8(11), 21335-21342.

[2] Akhmad,S.(2008). Teori-Teori Motivasi. Motivasi Artikel Pendidikan http://akhmadsudrajat. woedpress.com/20008/02/06/teori-teorimotivasi.

[3] Lim Arora, S., Vatsa, M., \& Dadhwal, V. (2008). A Comparison of Cabbage Leavesvs. Hot and Cold Compresses in the Treatment of Breast Engorgement. Indian Journal of Community Medicine: Official Publication of Indian Association of Preventive \& Social Medicine, 33(3), 160-162.

[4] Deswani, Gustina dan Rochimah.(2014). Efek placebo kompres daun kol dalam mengatasi pembengkakan payudara pada ibu post partum.

[5] Guyton And Hill.(2007). Buku Ajar Fisiologi Kedokteran Edisi 11: Jakarta:EGC.

[6] Genae D. Strong.(2011). Provider Management and Support for Breastfeeding Pain, Journal of Obstetric, Gynecologic \& Neonatal Nursing, Volume 40, Issue 6, 2011, Pages 753- 764, ISSN 0884-2175.

[7] Khosravan S.(2015). The Effect of Hollyhock (Althaea Officinalis L) Leaf Compresses Combined With Warm and Cold Compress on Breast Engorgement in Lactating Women: A Randomized Clinical Trial. Journal of Evidence-Based Complementary \& Alternative Medicine [J Evid Based Complementary Altern Med] 2015 Nov 23. Date of Electronic Publication: 2015 Nov 23.
[8] Kumar, A., et al.(2010). "Erythrina variegata Linn: A review on morphology, phytochemistry, and pharmacological aspects." Pharmacognosy Reviews, vol. 4, no. 8, 2, p. 147. Health Reference Center.

[9] Rukachaisirikul T, et al .(2007) Biological activities of the chemical constituents of Erythrina stricta and Erythrina sub umbras . Arch Pharm Res;30:1398-403Leveno, Kenneth J., et al. (2009). Obstetri Williams. EGC: Jakarta

[10] Mohrbacher, Nancy.(2010). Breastfeeding Made Simple: Seven Natural Laws for Nursing Mothers (2nd ed.). New Harbinger Publications Inc: Oakland

[11] Murniati.(2013). Hubungan Pengetahuan Ibu Nifas Tentang Bendungan ASI dengan Praktik Pencegahan Bendungan ASI. Jurnal Unimus Semarang.

[12] Nengah dan Surianti.(2013).Pengaruh pemberian Kompres Panas terhadap Intensitas Nyeri Pembengkakan Payudara Ibu Post Partum.(online).

[13] Prawirohardjo.(2009). Ilmu Kebidanan:Jakarta; Yayasan Bina Pustaka Sarwono.

[14] Sopiyani, Lia (2014) Hubungan Antara Dukungan Sosial (Suami) Dengan Motivasi Memberikan Asi Eksklusif Pada Ibu-Ibu Di Kabupaten Klaten. Skripsi thesis, Universitas Muhammadiyah Surakarta. http://eprints.ums.ac.id/30744/

[15] Witt and Bolman.(2015), Therapeutic Breast Massage in Lactation for the Management of Engorgement, Plugged Ducts, and Mastitis. Journal Of Human Lactation: Official Journal Of International Lactation Consultant Association [J Hum Lact] 2015 Dec 7. Date of Electronic Publication: 2015 Dec 7.

Citation: Sri Rahayu \& Ida Ariyanti. Erythrina Sub Umbrans as Hot and Cold Compression Therapy for Engorgement and Pain Intensity in Breast during Post Natal Bleeding. ARC Journal of Public Health and Community Medicine.2017; 2(3):53-56: dx.doi.org/10.20431/2456-0596.0203009

Copyright: (0) 2017 Authors. This is an open-access article distributed under the terms of the Creative Commons Attribution License, which permits unrestricted use, distribution, and reproduction in any medium, provided the original author and source are credited. 